\title{
PAJUBÁ: MANIFESTAÇÃO DO ETHOS NA POLARIZAÇÃO DISCURSIVA
}

\author{
Luis Henrique Boaventura* \\ Kaian Lago** \\ Ernani Cesar de Freitas ${ }^{* * *}$
}

O objetivo neste estudo é compreender o processo de polarização entre o discurso de liberalismo social (pró-LGBT+), expresso pelo jargão Pajubá, e o discurso de conservadorismo social (antiLGBT+), expresso pelo contradiscurso ultraconservador cristão. Utilizaremos, para a análise, as contribuições de Volóchinov (2017) (Círculo de Bakhtin) voltadas à natureza e à manifestação ideológica dos enunciados; Landowski (2016) sobre identidade e segregação nos grupos sociais linguísticos; Maingueneau (2013) acerca das manifestações do ethos discursivo, além de referenciais complementares. Nossa pesquisa é exploratória e bibliográfica, com análise qualitativa. O corpus escolhido para análise é um post criado pela psicóloga Marisa Lobo, em 5/11/2018, na rede social Instagram, referindo-se ao Pajubá. $\mathrm{O}$ estudo nos permite elucidar que manifestações discursivas ideologicamente contrárias fazem pressão em lados opostos - o lado "a" força o lado "b" a criar um contradiscurso oposto a ele para representar a sua identidade, e vice-versa.

Palavras-chave: Pajubá. Ethos; LGBT; Identidade; Polarização.

\section{INTRODUÇÃO}

$\mathrm{Na}$ era da liberdade de expressão, não é incomum nos depararmos com um cenário de polarização política e social, especialmente quando a intolerância e o preconceito surgem como formas opositoras ao contexto "aberto" da multiplicidade expressiva. Como exemplo disso, tivemos, em 2018, uma considerável polêmica envolvendo o jargão ${ }^{1}$ LGBT+ Pajubá, quando uma das questões do Exame Nacional do Ensino Médio (Enem) referenciou o repertório, causando um grande murmúrio nos setores mais conservadores da sociedade. Surgiram, em vista disso, diversos discursos apoiando a decisão do Enem e diversos

\footnotetext{
* Universidade de Passo Fundo, Av. Brasil Leste, 285 - São José, Passo Fundo - Rio Grande Sul, CEP $99052-$ 900, Brasil.. E-mail: luishboaventura@hotmail.com.

(iD) https://orcid.org/0000-0003-0292-6766

** Universidade de Passo Fundo, Av. Brasil Leste, 285 - São José, Passo Fundo - Rio Grande Sul, CEP 99052-900, Brasil. E-mail: k_spricigol@live.com.

iD https://orcid.org/0000-0001-7760-0184.

*** Universidade de Passo Fundo, Programa de Pós-Graduação em Letras, Av. Brasil Leste, 285 - São José, Passo Fundo - Rio Grande Sul, CEP 99052-900, Brasil. E-mail: ecesar@upf.br.

(iD https://orcid.org/0000-0002-8920-9446.

1 Utilizaremos o termo "jargão" para designar o fenômeno linguístico do Pajubá (popularmente referido como "dialeto gay") por melhor se enquadrar na visão adotada pelo artigo sobre a variante. Reiteramos que o foco deste artigo não é a classificação do fenômeno do Pajubá como dialeto ou como jargão, o que deverá ser matéria para pesquisas posteriores.
} 
discursos opostos à ideia (contradiscursos), advindos, principal e respectivamente, do meio LGBT+ e do grupo imediatamente oposto a ele no meio social, constituído pela massa ultraconservadora cristã ${ }^{2}$ heteronormativa.

Refletimos, sob esse espectro, a respeito do discurso LGBT+ expresso por meio do jargão Pajubá e a oposição ocasionada por ele sob a forma de um contradiscurso ultraconservador, representando dois lados oposto-complementares no movimento linguístico interacional polarizado. Em vista disso, nos baseamos na seguinte questão norteadora: o efeito de polarização surge como um modo de defesa social e linguística para manutenção da identidade de coletividades que prezam pela integridade de seu discurso e dos aspectos que as fazem pertencer a determinados conjuntos de valores $\mathrm{e}$ posicionamentos. Desse modo, o objetivo neste estudo é compreender o processo de polarização entre o discurso de liberalismo social (pró-LGBT+), expresso pelo jargão Pajubá, e o discurso de conservadorismo social (anti-LGBT+), expresso pelo contradiscurso ultraconservador cristão.

Utilizaremos, para a análise, as contribuições de Volóchinov (2017) voltadas à natureza e à manifestação ideológica dos enunciados — demonstrando que as ideologias são constitutivas da expressão identitária do sujeito em sociedade; Landowski (2016) sobre identidade e segregação nos grupos sociais linguísticos, marcando o fenômeno da polarização como aspecto primariamente social; e Maingueneau (2013) acerca das manifestações do ethos discursivo como elemento de identidade social, especialmente no contexto contemporâneo marcado pela influência digital; além de referenciais complementares. Nossa pesquisa é exploratória e bibliográfica, com análise qualitativa. Por sua vez, o corpus escolhido para análise é um post criado pela psicóloga Marisa Lobo, em 5/11/2018, na rede social Instagram, que se refere ao Pajubá.

O presente estudo está organizado da seguinte maneira: na seção 2, intitulado "A identidade no meio social: as vozes do eu e do outro", comentaremos sobre as questões identitárias que constituem as vozes sociais dos grupos minoritários e majoritários da nossa sociedade, segundo diferentes fatores. Em seguida, na seção 3, intitulado "O ethos e a expressividade coletiva", aprofundaremos a discussão para o ponto de vista discursivo,

\footnotetext{
2 É importante reforçar que um membro da fé cristã não subscreve automaticamente às visões típicas sustentadas pelos dogmas religiosos que vão de encontro às posições da comunidade LGBT+. A ênfase sobre o termo "cristã" é tomada emprestada, neste artigo, do ato linguístico praticado pela psicóloga Marisa Lobo que refere a si mesma publicamente como "psicóloga cristã" com vistas a conquistar adeptos e seguidores dessa fé em específico. O termo é parte integral do ethos que Marisa Lobo pretende projetar.
} 
demonstrando o processo da polarização dos discursos sociais e evidenciando a presença do terreno de influências, marcado pelo embate ideológico. $\mathrm{Na}$ seção 4, trataremos dos procedimentos metodológicos para, por fim, partirmos para a análise do corpus em "5 O embate identitário-ideológico: Pajubá como moeda de troca por likes" e para as considerações finais.

\section{A IDENTIDADE NO MEIO SOCIAL: AS VOZES DO EU E DO OUTRO}

Falar em identidade social é o mesmo que referenciar a ação da vOz e da consciência individual como fator social ideológico. Volóchinov (2017, p. 97) diz que "a consciência se forma e se realiza no material sígnico criado no processo da comunicação social de uma coletividade organizada". Sendo assim, não há consciência individual sem material sígnico ou comunicação social, e vice-versa. A consciência individual é um fato social e ideológico. (VOLÓCHINOV, 2017, p. 97, grifo do autor).

Por ser fato social e ideológico, a identidade se constrói a partir do movimento de interação verbal entre os indivíduos que representam uma ou mais coletividades, constituindo uma "voz" única e individual — que é a manifestação enunciativa dessa identidade. Da mesma forma, a identidade individual é construída também pelo outro e para o outro, uma vez que a interação social se inicia pelo contato discursivo entre as consciências individuais que originarão uma voz para cada indivíduo coenunciador.

É insuficiente ver a instância subjetiva que se manifesta por meio do discurso apenas como estatuto ou papel. Ela se manifesta também como "voz" e, além disso, como "corpo enunciante", historicamente especificado e inscrito em uma situação, que sua enunciação ao mesmo tempo pressupõe e valida progressivamente (MAINGUENEAU, 2013, p. 70).

No quadro da sociedade marcada por intensa polarização entre grupos sociais, vemos a reflexão dessa voz do "eu” assumida de um viés não mais individual, mas coletivo. Nesse contexto, um jargão surge como uma manifestação dessa forma "eu-coletividade", estandarte de um conjunto de consciências individuais com ideologias em comum e um ato responsivo de legitimação ideológica social. "É por isso que todas as ênfases ideológicas [...], são ênfases sociais, que pretendem o reconhecimento social” [...] (VOLÓCHINOV, 2017, p. 111, grifos do autor). Além disso, para que haja tal singularidade identitária, a única 
maneira vista pelo indivíduo-coletividade de expressar sua voz é expondo que ela não é igual à voz do outro indivíduo-coletividade: "eu sou eu porque não sou você".

O sujeito tem necessidade de um ele - dos "outros" (eles) - para chegar à existência semiótica, e isso por duas razões. Com efeito, o que dá forma à minha própria identidade não é só a maneira pela qual, reflexivamente, eu me defino (ou tento me definir) em relação à imagem que outrem me envia de mim mesmo; é também a maneira pela qual, transitivamente, objetivo a alteridade do outro atribuindo um conteúdo específico à diferença que me separa dele. (LANDOWSKI, 2016, p. 4, grifo do autor).

Nos é necessário, aqui, fazer uma breve recapitulação da origem do Pajubá. De acordo com Cruz e Tito (2016), o Pajubá teve origem na língua Iorubá, da família linguística nígero-congolesa. Resumidamente, o Iorubá veio para o Brasil com o tráfico transatlântico de africanos, entre os séculos XVI e XIX. Por ser parte da identidade africana - predominantemente nigeriana - a língua fixou-se nas religiões afro-brasileiras, de longe uma das maiores heranças da cultura africana no nosso país.

Paralelo a isso, ao considerarmos a natureza de forte repressão sexual por parte das principais práticas religiosas no Brasil, que força pessoas LGBT $+\mathrm{s}$ a procurar amparo sociocultural no ateísmo ou em práticas religiosas mais liberais, a adesão às religiões afrobrasileiras, sobretudo ao Candomblé, passa a fazer mais sentido. "[...] visto que socialmente ocorre este tipo de acusação: terreiros de Candomblé são frequentados por homossexuais" (CRUZ; TITO, 2016, p. 16).

O jargão Pajubá originou, então, um contradiscurso completamente avesso às ideologias identitárias do grupo LGBT+ e da população nigeriana, por consequência. Um dos componentes que marcou a argumentação criada por esse contradiscurso foi a adoção do termo "ideologia de gênero", sob tons pejorativos. Embora, segundo Junqueira (2017, p. 221), o termo tenha se originado sob a forma de "uma invenção católica que emergiu sob os desígnios do Conselho Pontifício para a Família e de conferências episcopais, entre meados da década de 1990 e no início dos 2000”, é fato que adquiriu novos significados coniventes às ideologias defendidas pelo meio ultraconservador cristão.

Em tal cenário de preservação discursiva mútua, cabe recapitular que o meio LGBT+, representado, nesse caso, pelo jargão Pajubá, qualifica uma minoria: segundo pesquisa independente realizada pelo grupo GGB (Grupo Gay da Bahia, 2018), estima-se que apenas $16,5 \%$ da população brasileira seja LGBT + . Por esse motivo, devemos levar em 
consideração outro coeficiente: a ascensão social daqueles que, marginalizados pelos grupos sociais preponderantes, não veem oportunidades discursivas de legitimar a sua identidade.

O grupo majoritário continuamente agirá como se o minoritário não tivesse nem mesmo uma identidade e, por isso, devesse assumir a identidade majoritária, já que ela, fortalecida e legitimada pela sociedade, seria muito mais agradável. "[O] Outro se encontra de imediato desqualificado enquanto sujeito: sua singularidade aparentemente não remete a nenhuma identidade estruturada" (LANDOWSKI, 2016, p. 7). O grupo majoritário confere, então, uma dupla "imagem" ou "propaganda" de sua identidade, baseando-se nos conflitos propiciados pela polarização discursiva.

A primeira seria destinada ao próprio grupo de polarização, tendo a finalidade de preservar a identidade de si como grupo dominante. A segunda, todavia, se caracterizaria pela "propaganda" dessa identidade ao grupo minoritário (Pajubá/LGBT. A fim de conseguirmos compreender melhor tal concepção, passaremos para o viés da expressividade coletiva ilustrada pelo ethos discursivo, no capítulo a seguir. Nesse sentido, a identidade e as respectivas vozes "eu-coletividade" serão refletidas na imagem discursiva constituída pelo ethos.

\section{O ETHOS E A EXPRESSIVIDADE COLETIVA}

O processo de persuadir por meio de uma imagem discursiva vem sendo discutido desde a retórica de Aristóteles. Entretanto, segundo Amossy (2013), foi apenas a partir da teoria polifônica da enunciação de Oswald Ducrot, que a imagem de si no discurso ganhou valor na semântica, sendo desenvolvida posteriormente pela análise do discurso de Maingueneau. O ethos discursivo vem, nessa concepção, como um "status" do enunciador (modo de se enunciar") "para legitimar seu dizer", marcando "sua relação com um saber" (AMOSSY, 2013, p. 16). Desse modo, representando uma intenção persuasiva de um enunciador que quer se fazer crível.

Ao aplicarmos a noção de ethos a marcas identitárias coletivizadas, vemos a formação de padrões certamente singulares. Para que o indivíduo expresse a sua identidade (e, consequentemente, suas ideologias por meio do discurso coletivo), torna-se necessária a criação de um ethos que ilustre as intenções da voz "eu-coletividade", mas que também

\footnotetext{
${ }^{3}$ Definição de “modo de enunciação" por Ruth Amossy (2013).
} 
sirva de objeto opositor à voz "eu-coletividade" alheia. Temos, em vista disso, duas instâncias de manifestação do ethos discursivo no plano da polarização: o ethos da preservação identitário-discursiva e o ethos da adesão identitário-majoritária.

\section{AS DUAS INSTÂNCIAS NO PLANO DA POLARIZAÇÃO}

$\mathrm{Na}$ primeira instância (preservação identitário-discursiva), ambas as vozes lutam para preservar a sua integridade ideológica. Para isso, projetam no discurso imagens que ilustram três afirmações ideológicas: a) somos isso; b) somos isso porque não somos aquilo; e c) jamais seremos aquilo. Esse processo força ambos os grupos a assumirem um estado discursivo extremista, baseado na preservação de sua identidade, criando, de um lado, padrões linguísticos muito específicos que limitam o seu uso (como o próprio Pajubá) e, de outro, adotando termos com conotações pejorativas - como "ideologia de gênero". A fim de compreendermos o repertório singular que orienta o vocabulário do jargão LGBT+, disponibilizamos, logo abaixo, no quadro 1, alguns dos termos mais recorrentes do jargão e seu significado/tradução.

Quadro 1: Breve dicionário de termos do jargão Pajubá.

\begin{tabular}{|cc|} 
Acuér & Dinheiro \\
Amapô & Mulher \\
Bofe & Homem bonito \\
Elza & Roubar \\
Mala & Sinônimo de pênis \\
Mati & Pequeno \\
Picumã & Cabelo \\
Ocó & Homem \\
Odara & Grande \\
Uó & Sinônimo de ruim \\
\hline
\end{tabular}


Fonte: MILLER, Victor. Dicionário Pajubá: conheça alguns dos termos populares entre LGBTs.

Considerando essas circunstâncias, podemos afirmar que ambos os discursos, em dado momento, integram contradiscurso, pois se opõem ao discurso identitário-ideológico do outro. Embora instintivo do processo enunciativo, esse seguimento discursivo também é segregacionista, pois exclui qualquer hipótese de assimilação do grupo antagonista, já que não o reconhece como parceiro de comunicação, conforme visto na Figura 1:

Figura 1: Ethos da preservação identitário-discursiva

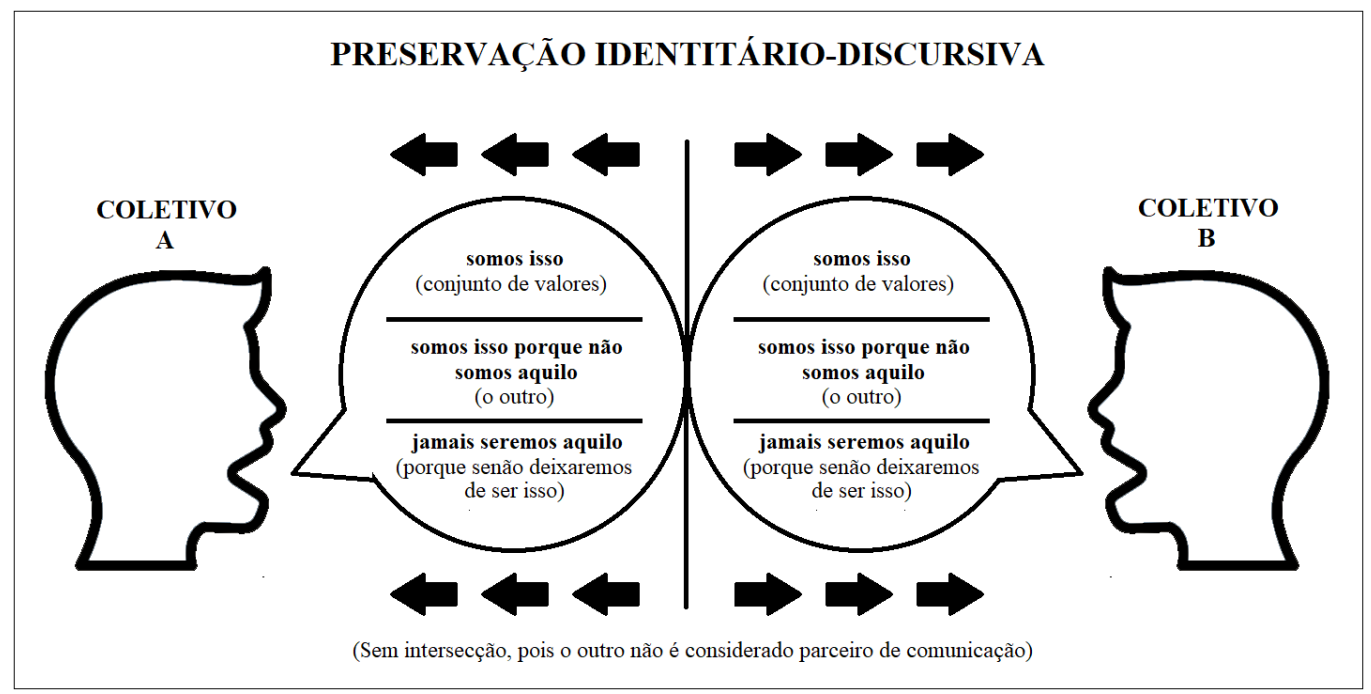

Fonte: Elaborada pelos autores

Por isso, essa primeira instância é destinada primariamente ao próprio grupo de polarização. Embora o processo de garantia da integridade linguística seja ingrediente de formação da primeira instância de ethos, é o próprio processo que originará a segunda instância, isto é, o ethos da adesão identitário-majoritária.

Sob a mesma premissa de garantir a sobrevivência linguística do coletivo no meio social, cria-se três novas afirmações ideológicas: a) não basta sermos isso se o outro continuar a ser aquilo; b) o outro apenas é aquilo porque não é isso; e c) aquilo deve ser isso para deixar de ser aquilo. Todo coletivo almeja um estado de envolvimento que aumente o alcance de seu discurso, e não há modo de atingi-lo sem o "recrutamento" ou a "adesão" de novos indivíduos ao grupo. Esse processo é ilustrado na Figura 2:

Figura 2: Ethos da adesão identitário-majoritária 


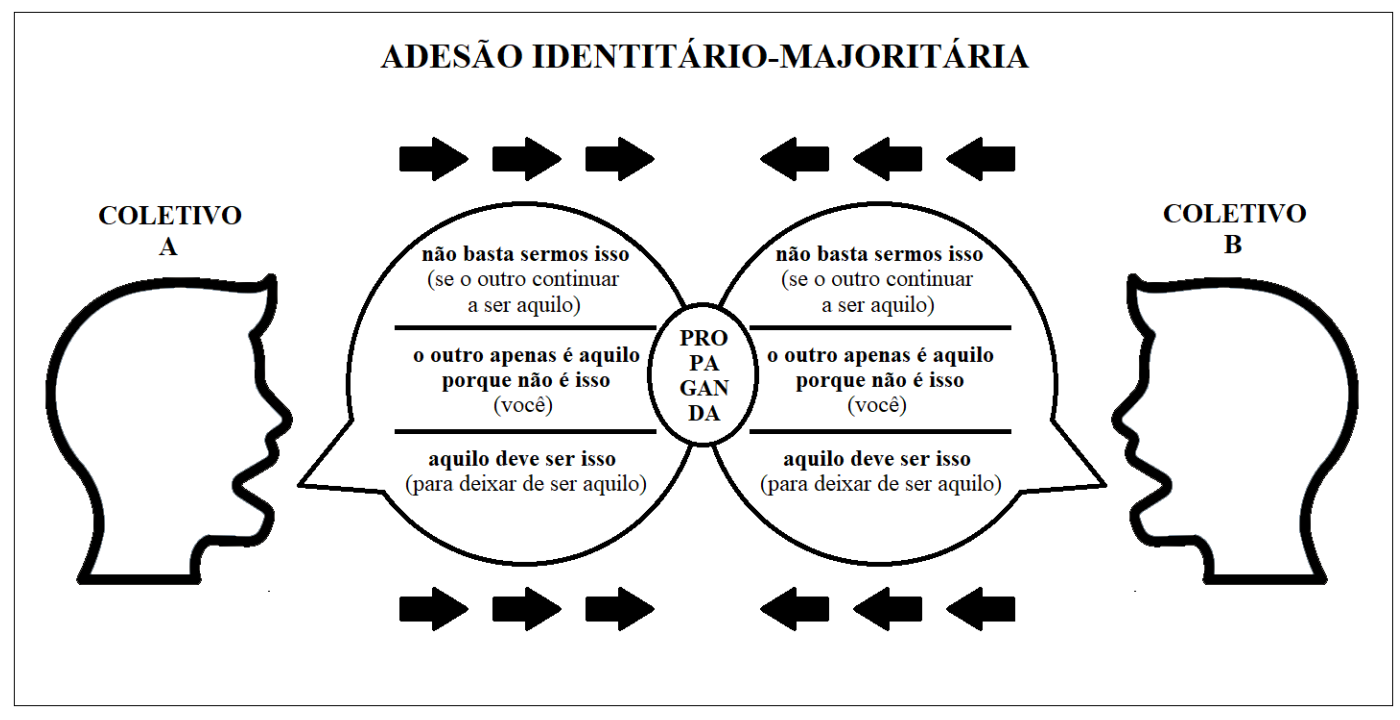

Fonte: Elaborada pelos autores

É a partir desse segundo ethos que ocorre a produção de uma "propaganda" de adesão do grupo, destinada ao outro extremo da linha polarizadora. Propaganda que leva em consideração o conjunto de valores arquetípicos do coletivo, determinantes para a sua identidade. Isto é, o que os faz ser "isso" e não "aquilo". Para enunciar esse conjunto de valores, inicialmente é necessária a criação de uma vocalidade que expresse esse posicionamento discursivo, em outras palavras, um “tom" específico que também caracterize a identidade do coletivo.

[...] o tom específico que torna possível a vocalidade constitui para nós uma dimensão que faz parte da identidade de um posicionamento discursivo. $\mathrm{O}$ universo de sentido que o discurso libera impõe-se tanto pelo ethos quanto pela "doutrina"; as "ideias" apresentam-se por uma maneira de dizer que remete a uma maneira de ser, à participação imaginária de um vivido. [...] $\mathrm{O}$ poder de persuasão de um discurso decorre em boa medida do fato de que leva o leitor a identificar-se com a movimentação de um corpo investido de valores historicamente especificados. (MAINGUENEAU, 2013, p. 73).

O conjunto de valores associado ao tom específico implicará em um estereótipo, pois os indivíduos da coletividade necessitam identificar-se com um ideal, ou identificar-se com um modelo a ser seguido, a ser "incorporado". Maingueneau (2013, p. 72) estabelece que a maneira pela qual o coenunciador se relaciona ao ethos de um discurso é pela incorporação. Para tanto, os representantes enunciativos da coletividade esforçam-se para transacionar essa imagem estereotípica de valores de sua identidade a um "fiador" que ateste a verdade e a credibilidade do seu discurso, de acordo com o que veremos a seguir. 


\section{O FIADOR E O PROCESSO DA INCORPORAÇÃO DE VALORES}

A necessidade de ser crível — seja para seu próprio grupo de polarização ou para outrem - requer uma compatibilidade identitária com aquilo que se é enunciado e/ou mostrado pelo ethos sob forma de ilustração do estereótipo arquetípico. "A qualidade do ethos remete, com efeito, à figura desse 'fiador' que, mediante sua fala, se dá uma identidade compatível com o mundo que se supõe que ele faz surgir em seu enunciado". (MAINGUENEAU, 2013, p. 73). Por isso, no caso de haver duas instâncias de ethos discursivo, há, do mesmo modo, dois fiadores, associados a uma questão identitária e estereotípica relativa a cada uma das coletividades. Esses fiadores assumem, em vista disso, dois caracteres e duas corporalidades, isto é, duas maneiras de "movimentar-se" no fio do discurso.

O "fiador", cuja figura o leitor deve construir com base em indícios textuais de diversas ordens, vê-se, assim, investido de um caráter e de uma corporalidade, cujo grau de precisão varia conforme os textos. O "caráter" corresponde a um feixe de traços psicológicos. Quanto à "corporalidade", ela é associada a uma compleição corporal, mas também a uma forma de vestir-se e de mover-se no espaço social. O ethos implica assim um controle tácito do corpo, apreendido por meio de um comportamento global. (MAINGUENEAU, 2013, p. 72)

Com efeito, o que determinará a natureza desse comportamento global manifestado pelo conjunto caráter/corporalidade da figura fiadora "eu-coletividade" é o ato intencional de persuasão direcionado a cada extremo. Um discurso agressivo pode ser persuasivo e fidedigno para um grupo social e o completo oposto para outro. "[...] qualquer discurso escrito, mesmo que a negue, possui uma vocalidade específica, que permite relacioná-lo a uma fonte enunciativa, por meio de um tom que indica quem o disse [...]." (MAINGUENEAU, 2013, p. 72).

O termo "ideologia de gênero", quando enunciado com voracidade pelo grupo ultraconservador cristão para o grupo ultraconservador cristão, configura uma dessas situações, uma vez que diminui o valor identitário-ideológico do meio LGBT+ a gênero (masculino/feminino). Do mesmo modo, a vocalidade auxilia, nesse ponto, na identificação dos "problemas de valores" do meio ultraconservador cristão, isto é, práticas e/ou ideologias que estariam ferindo os costumes tradicionais desse coletivo. Cunha (2019, p. 32) argumenta o seguinte: 
O discurso político enxerga a homossexualidade como um problema de ordem moral, pois, ao passo que o discurso religioso tem como função catequizar e doutrinar o sujeito de acordo com sua visão de mundo, seja físico ou metafísico, e assim sendo uma parte de sua constituição moral, o discurso político tem a função de, não apenas preservar o status quo das estruturais e instituições sociais, como também vigiar, perseguir e punir aqueles que vão contra "a moral e os bons costumes".

Assim, os representantes do meio ultraconservador cristão procuram se tornar corpo investido de valores religiosos tradicionais sobre família e comportamento heteronormativo cisgênero para validar um discurso fonte que é o único ideal a ser seguido pelo próprio grupo na esfera da polarização. Porque qualquer outro ideal que fuja do ideológico-identitário pertencente ao grupo, pertencerá a outra coletividade (até mesmo a antagonista). Cunha (2019, p. 32-33) apresenta um breve panorama da homofobia política no Brasil, segundo estas considerações:

Usada constantemente como moeda de campanhas políticas, a homofobia política aparece aqui como defensora da família, da moral, dos costumes e das instituições, necessárias para a manutenção de um Estado e de uma sociedade saudável, ameaça por uma suposta distorção e subversão moral. O discurso religioso e político aqui se misturam de tal forma que acaba sendo quase impossível diferenciar um do outro, colocando em xeque até mesmo a própria laicidade do Estado. (CUNHA, 2019, p. 32-33).

Mais do que um ideal a ser seguido, o estereótipo da coletividade mostra-se um gene constitutivo para o discurso coletivo, pois, sem ele, o coletivo não é aquilo que o faz ser o coletivo. O elo entre o enunciador e a situação de comunicação é inquebrável, uma vez que “[...] qualquer discurso, por seu próprio desdobramento, pretende instituir a situação de enunciação que o torna pertinente" (MAINGUENEAU, 2013, p. 75-90). O enunciador pode não se dar conta, mas cada movimento político manifestado por ele durante a enunciação, é determinante para a criação dessa situação ideológica, identitária e persuasiva, mas também relativa a cada esfera social, como o caso a ser estudado das redes sociais, ou social media.

\section{A ESFERA POLÍTICA NA SOCIAL MEDIA}

O discurso político, por sua natureza, é construído pela oposição a outro discurso para "vender" seus argumentos como mais válidos a um terceiro elemento, no caso o 
“alvo" político, de onde o representante angariará os votos, a representatividade etc., sendo assim um discurso competitivo, gamificado. No contexto da social media, gamificada pelo processo de angariar likes, comments, shares etc., pode-se afirmar que se origina um espectro polarizante (Boaventura, 2017).

No Instagram, as publicações — que combinam discurso verbal com não-verbal — produzem um sentido altamente persuasivo ao coenunciador primário, seus followers (seguidores). Assim, a legitimidade interliga-se em atitudes discursivas que devem ser assumidas pela voz "eu-coletividade" para efeito de reiteração de seu discurso não mais de preservação, mas puramente político, com foco em sua própria coletividade.

Via de regra, o discurso que provém do "outro" não é considerado legítimo para que mereça uma resposta legítima, sendo utilizado como mera base para afixação de uma figura (um antagonista, antifiador) que terá então uma função na encenação do enunciador com objetivo de persuadir um outro coenunciador, ocupante do lado comum do debate. (BOAVENTURA, 2018, p. 454)

Nesse caso, a presença da voz do outro grupo "eu-coletividade" apenas é apropriada pelo grupo majoritário como forma de: a) instauração de um dispositivo de segregação discursiva de preservação, amparada pelo primeiro ethos (o ethos da preservação identitário-discursiva) e b) persuasão do coenunciador esperado, constituído pelo próprio grupo de polarização, apoiada nos moldes do estereótipo, da hierarquia e da soberania do grupo, que reconhece o seu valor como grupo majoritário e, por isso, ampara-se no segundo ethos (o ethos da adesão identitário-majoritária), que regularmente seria destinado ao grupo oposto de polarização.

Apreendidos os fenômenos que regulam a expressividade coletiva no embate identitário e ideológico que implicam ethos discursivos, passamos para os procedimentos metodológicos a fim de compreender o processo de análise no presente estudo para, em seguida, partirmos para a análise do corpus selecionado.

\section{PROCEDIMENTOS METODOLÓGICOS}

Nossa pesquisa afigura-se exploratória e bibliográfica, com análise qualitativa. O corpus escolhido para análise é um post criado pela psicóloga cristã Marisa Lobo, em 5/11/2018, na rede social Instagram, referindo-se ao Pajubá. A análise será regida segundo 
arcabouço teórico de Volóchinov (2017) (Círculo de Bakhtin), voltado à natureza e à manifestação ideológica dos enunciados; Landowski (2016) pertinente à identidade e segregação nos grupos sociais linguísticos; e Maingueneau (2013) acerca das manifestações do ethos discursivo como elemento de identidade social.

A análise do corpus será realizada a partir da reprodução do post criado e da transcrição dos trechos verbais que constituem a legenda. Justificamos a escolha do corpus a partir das concepções de Maingueneau (2013, p. 87) de que "a foto faz ver uma representação do fiador em movimento em um espaço social determinado". As observações e os argumentos estão organizados da seguinte maneira:

a) inicialmente, faremos uma contextualização dos discursos da enunciadora, inserindo, logo em seguida, o corpus escolhido e comentando sobre a representatividade de seu discurso para o coletivo ultraconservador cristão;

b) em seguida, analisamos o comentário da psicóloga a partir de dez argumentos-chave, do ponto de vista da preservação identitário-ideológica (preservação do discurso do coletivo), mostrando as implicâncias e as referências existentes em cada um deles;

c) ao final, determinamos o ponto de vista da adesão (influência) no contexto político da social media, acerca de que forma a psicóloga enuncia e quais são os ethos criados para convencer seu próprio grupo de polarização e o grupo antagonista a atribuírem credibilidade a seu fiador.

Assim sendo, partimos para a análise do corpus.

\section{O EMBATE IDENTITÁRIO-IDEOLÓGICO: PAJUBÁ COMO MOEDA DE TROCA POR LIKES}

A fim de compreendermos, de modo satisfatório, as reações enunciativas do grupo ultraconservador cristão frente à presença do jargão Pajubá no Enem, trazemos, inicialmente, a reprodução da referida questão, na figura $3, \operatorname{logo}$ abaixo. Note que o enfoque do enunciado da questão está nos pontos: a) o Pajubá como dialeto; e b) o Pajubá como patrimônio linguístico. Sendo assim, em momento algum é incentivado o seu uso 
pelos grupos não-LGBT+s, marcando, em seu lugar, a sua representatividade como forma de variação linguística.

Figura 3: Questão do Enem referente ao Pajubá

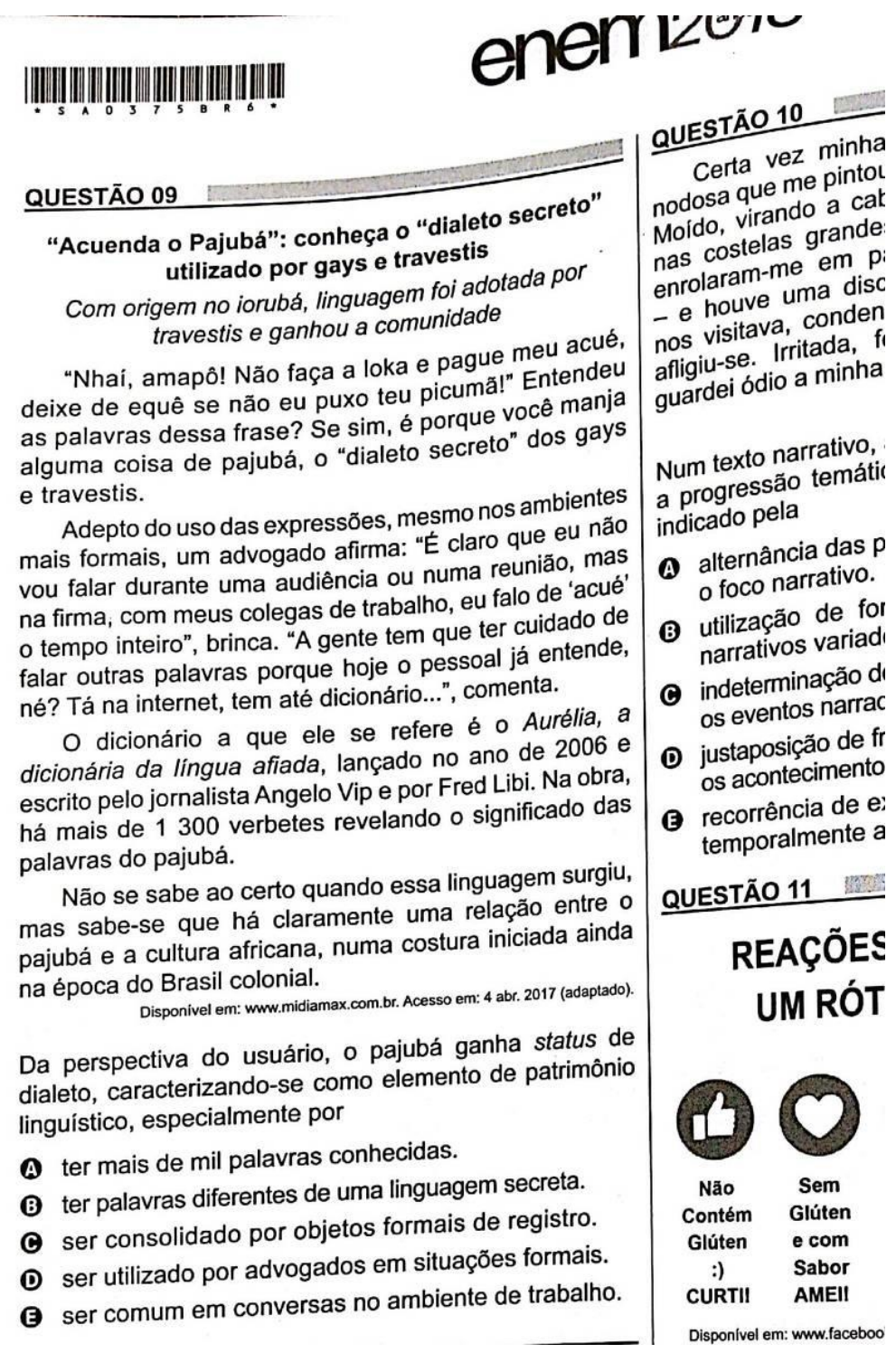

Fonte: Bolsonaro critica questão do Enem sobre gays e promete exame com temas 'úteis' (FOLHA DE S. PAULO, 2018)

Embora o corpus analisado seja representativo do discurso ultraconservador cristão, é necessário esclarecer, aqui, que este mesmo discurso é reproduzido pela enunciadora de muitas outras formas nas redes sociais. Por isso, de modo a oferecer a dimensão desses discursos, bem como esclarecer a construção discursiva de seu processo enunciativo, apresentamos, a seguir, seis exemplares (posts) de seu discurso na plataforma 
Instagram, que, em função da limitação de espaço, não serão analisados aqui. Acompanhe as figuras 4 a 9 :

Figura 4: Recorte 1

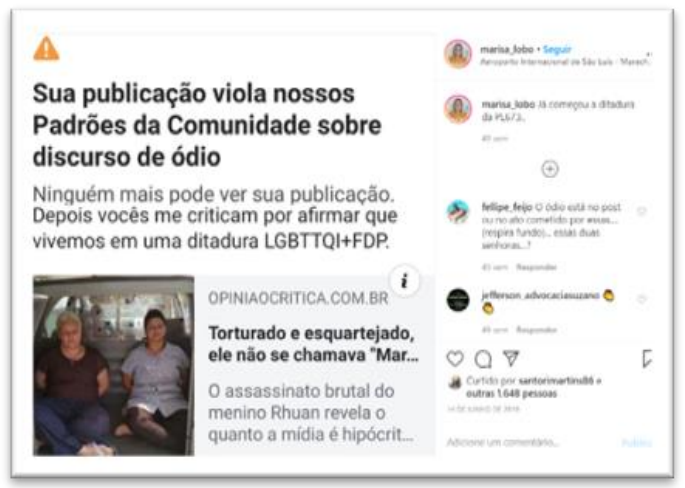

Fonte: Instagram (2019)

Figura 6: Recorte 3

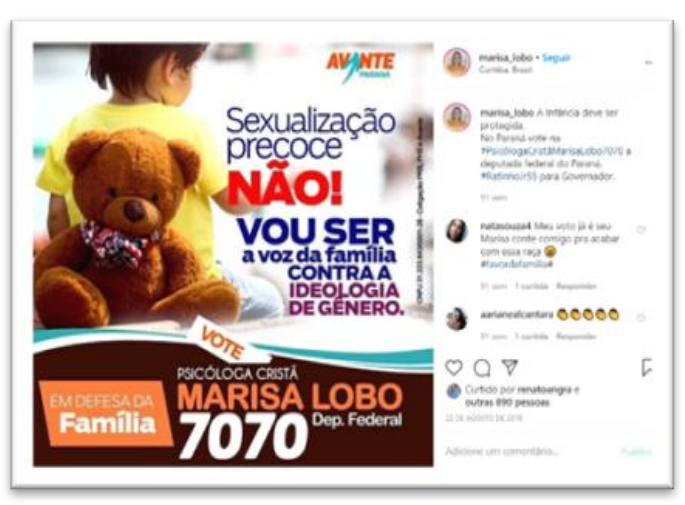

Fonte: Instagram (2018)
Figura 5: Recorte 2

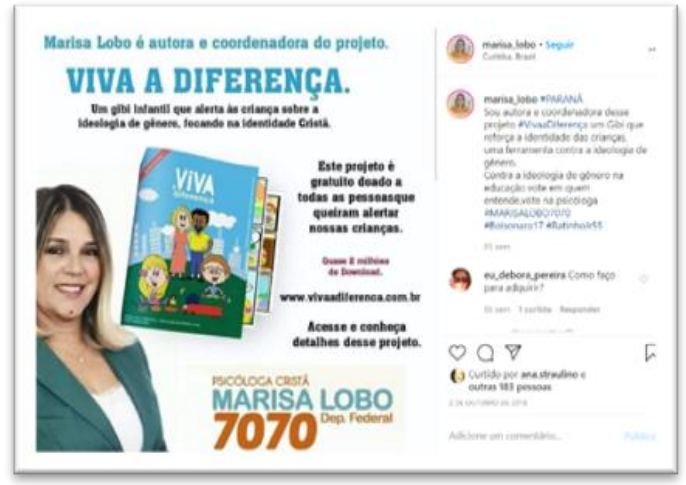

Fonte: Instagram (2018)

Figura 7: Recorte 4

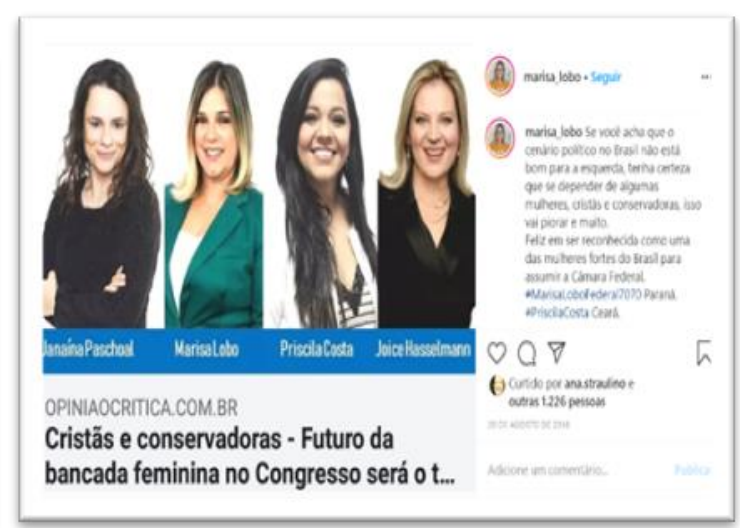

Fonte: Instagram (2018)

Figura 8: Recorte 5

Figura 9: Recorte 6 


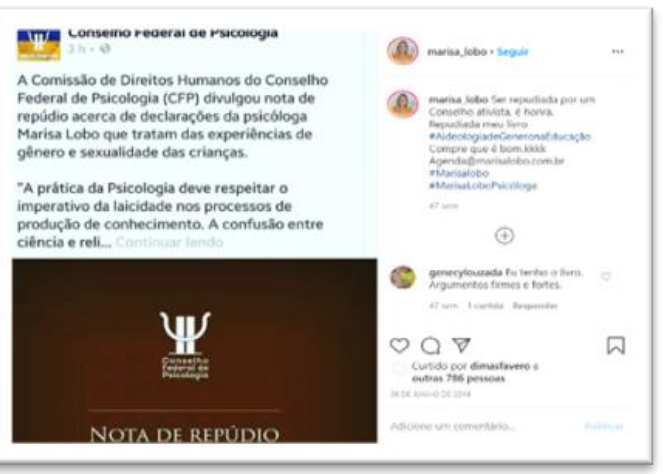

Fonte: Instagram (2019)

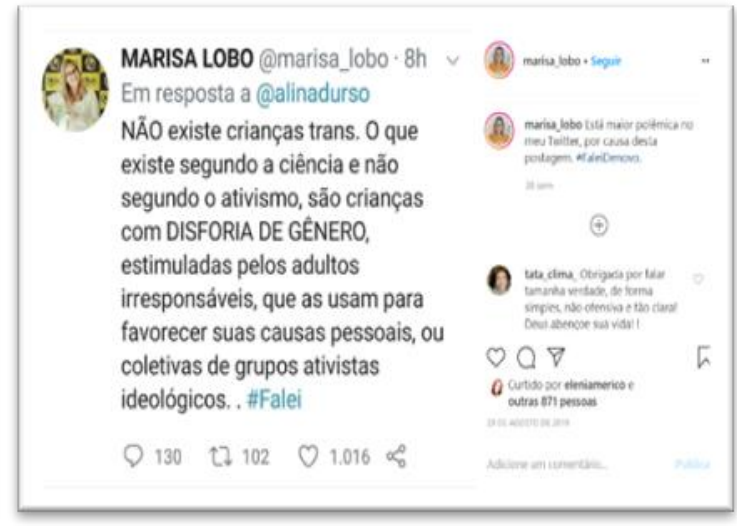

Fonte: Instagram (2019)

Frequentemente, a psicóloga associa ideais de esquerda/LGBT+ à noção pejorativa de "ideologia de gênero" ou sexualização precoce (como nas figuras 5, 6 e 9), refuta pesquisas científicas atreladas ao público LGBT+ como propaganda ideológica, credibilizando a pseudociência de seu coletivo no processo (figuras 7, 8 e 9). Há, inclusive, referência ao movimento LGBT+ como “ditadura LGBTTQI+FDP” (figura 4). Esses recortes apresentam a recorrência aos valores ultraconservadores cristãos e, inclusive, seus efeitos no espectro polarizante. Além destes, trazemos, também, para efeito complementar, recorte de notícia publicada em 05/11/2018, desta vez problematizando a posição do presidente recém eleito Jair Messias Bolsonaro que defende opinião similar à da psicóloga, referente ao Pajubá. Acompanhe a figura 10: 
Figura 10: Bolsonaro critica questão do Enem referente ao Pajubá

$30 / 06 / 2020$

Bolsonaro critica questão do Enem sobre gays e promete exame com temas 'úteis' - 05/11/2018 - Educaçăo - Folha

\title{
FOLHA DE S.PAULO
}

$\star \star \star$

ELEIÇÖES 2018 (HTTPS://WWW1.FOLHA.UOL.COM.BR/PODER/ELEICOES/2018)

\section{Bolsonaro critica questão do Enem sobre gays e promete exame com temas 'úteis'}

\author{
Presidente eleito disse que não vai acabar com exame, mas tratará da questão de \\ outra forma \\ 5.nov. 2018 às $17 \mathrm{~h} 46$ \\ Atualizado: 5. nov. 2018 às $17 \mathrm{~h} 56$ \\ 国 EDIÇÄO IMPRESSA (https://www1.folha.uol.com.br/fsp/fac-simile/2018/11/06/)
}

SÃo PAULO|UOL O presidente eleito Jair Bolsonaro (PSL) criticou nesta segunda-feira (5) uma questão da prova do Enem (Exame Nacional do Ensino Médio) (http://www.agora.uol.com.br/saopaulo/2018/11/1984047-1-dia-do-enem-tem-questoes-sobre-feminismo-e. ditadura.shtml) que tratava do "dialeto secreto" utilizado por gays e travestis e disse que sua gestão no Ministério da Educação "não tratará de assuntos dessa forma". No último domingo, cerca de 5,5 milhões de candidatos prestaram o exame em todo o país.

"Uma questão de prova que entra na dialética, na linguagem secreta de travesti, não tem nada a ver, não mede conhecimento nenhum. A não ser obrigar para que no futuro a garotada se interesse mais por esse assunto. Temos que fazer com que o Enem cobre conhecimentos úteis", disse o capitão reformado em entrevista ao vivo ao apresentador José Luiz Datena no Brasil Urgente, da Band.

Bolsonaro negou que pretenda acabar com o exame, mas disse que seu governo não vai "ficar divagando sobre questões menores". "Ninguém quer acabar com o Enem, mas tem que cobrar ali o que realmente tem a ver com a

Fonte: Bolsonaro critica questão do Enem sobre gays e promete exame com temas 'úteis' (FOLHA DE S. PAULO, 2018)

Novamente, há a referência aos valores ultraconservadores cristãos. Ao dizer que a referida questão "não tem nada a ver, não mede conhecimento nenhum, [a] não ser obrigar para que no futuro a garotada se interesse mais por esse assunto", o presidente recorre à ideia pejorativa de ideologia de gênero, mesmo que não a mencione diretamente. Assim, o Pajubá é visto como um desvio, uma inconveniência, uma deturpação dos valores morais. Veremos, a seguir, que o mesmo processo ocorre no corpus analisado. O post de Marisa Lobo é reproduzido na Figura 11: 

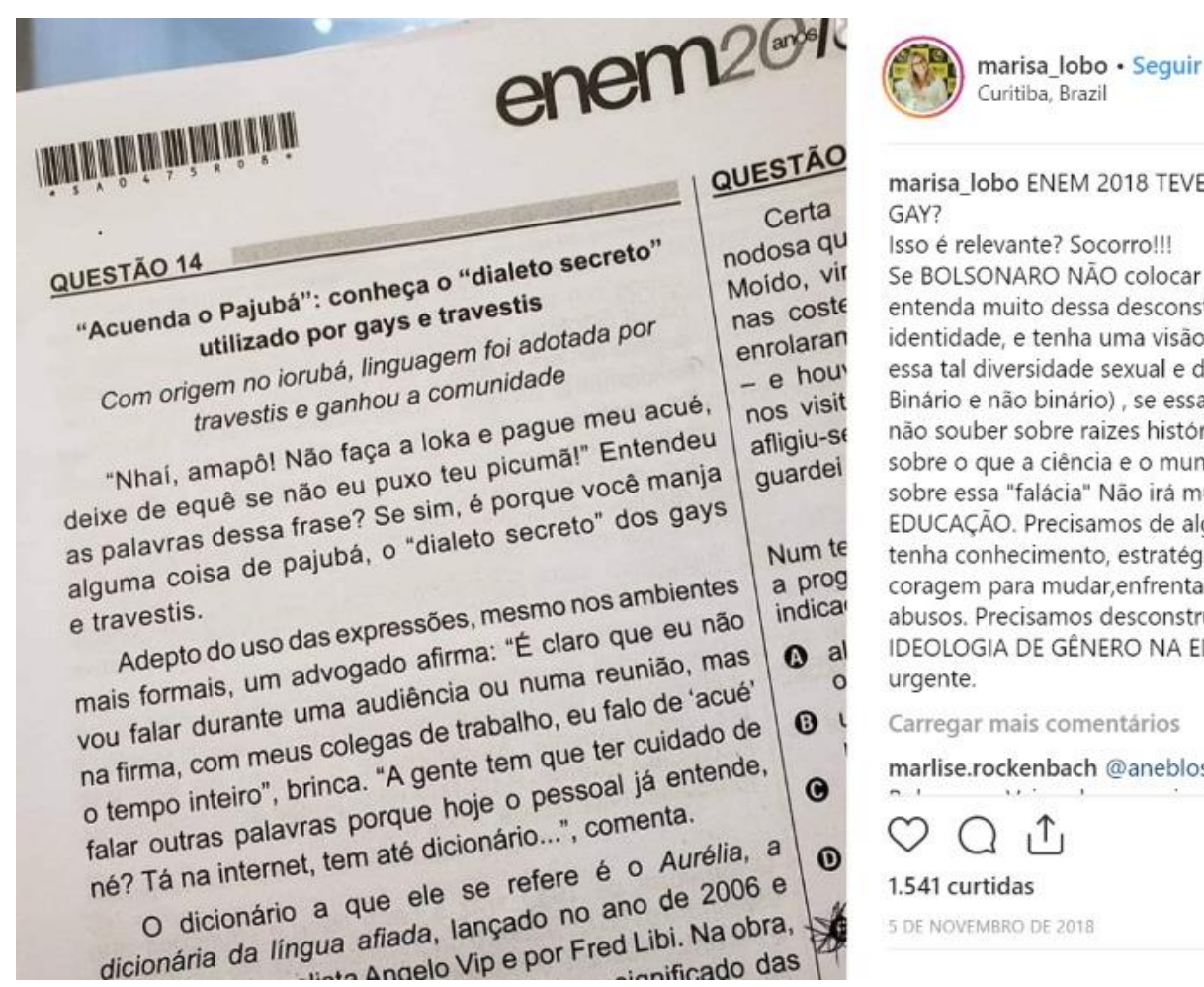

marisa_lobo ENEM 2018 TEVE ATÉ DIALETO GAY?

Isso é relevante? Socorro!!!

Se BOLSONARO NÃO colocar alguém que entenda muito dessa desconstrução da identidade, e tenha uma visão critica sobre essa tal diversidade sexual e de gênero ( Binário e não binário) , se essa tal pessoa, não souber sobre raizes históricas,lógica, e sobre o que a ciència e o mundo afirma sobre essa "falácia" Não irà mudar nossa EDUCAÇĀO. Precisamos de alguém que tenha conhecimento, estratégico e coragem para mudar,enfrentar esses abusos. Precisamos desconstruir essa IDEOLOGIA DE GÊNERO NA EDUCAÇÃO. É urgente.

\section{Carregar mais comentários}

marlise.rockenbach @anebloss e Viva

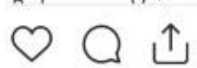

1.541 curtidas

Fonte: Instagram (2018)

Sem reconhecer o grupo antagonista como parceiro de comunicação, a enunciadora defende uma interpretação caricata do jargão Pajubá, o que, segundo Landowski (2016, p. 6), pode ser explicado pela noção de que "toda diferença de comportamento um pouco marcada, pela qual o estrangeiro trai sua proveniência, parece, para ele, extravagância despida de razão". Ao invocar o próprio grupo de polarização, a psicóloga introduz a primeira instância de ethos, relativa ao senso de autopreservação do coletivo (preservação identitário-discursiva), forçando-o a dirigir-se a seu próprio grupo, como podemos observar na Figura 12: 
Figura 12: Preservação identitário-discursiva dos grupos LGBT+ e anti-LGBT+

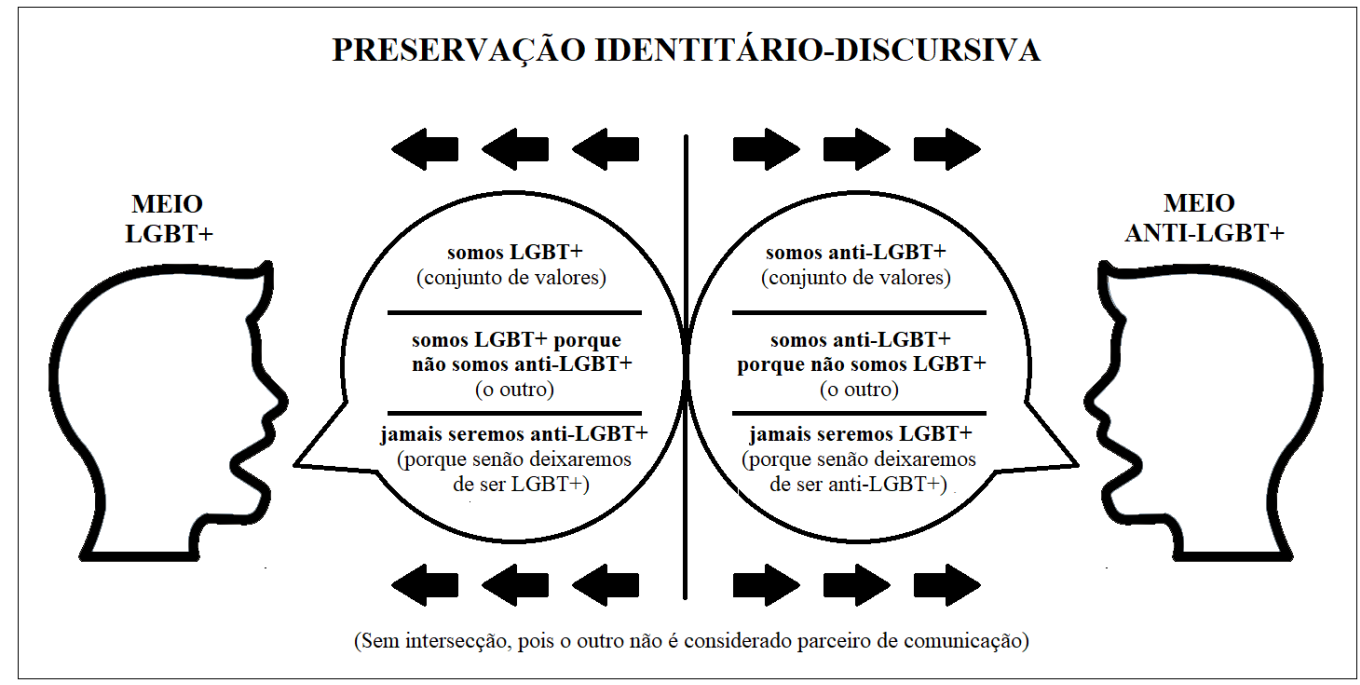

Fonte: Elaborada pelos autores.

De modo geral, o comentário da psicóloga poderia ser dividido em dez argumentos-chave, que regem o processo de defesa linguística e atestação da voz coletiva. São eles: a) ENEM 2018 TEVE ATÉ DLALETO GAY?; b) Isso é relevante? Socorro!!!; c) Se BOLSONARO NÃO colocar alguém [...]; d) [...] dessa desconstrução da identidade [...]; e) essa tal diversidade sexual e de gênero; f) se essa tal pessoa não souber sobre raizzes históricas, lógica [...]; g) sobre o que a ciência e o mundo afirma sobre essa "falácia"; h) Não irá mudar nossa EDUCAÇÃO; i) Precisamos de alguém que tenha conhecimento, estratégico e coragem para mudar, enfrentar esses abusos; e j) Precisamos desconstruir essa IDEOLOGLA DE GÊNERO NA EDUCAÇÃO. É urgente.

O discurso da enunciadora é voltado à preservação de sua identidade em oposição à identidade Pajubense (constituída tanto pelos falantes, quanto pelos adeptos a reconhecer o valor enunciativo do jargão na sociedade), pois "um sujeito não pode, no fundo, apreenderse a si mesmo enquanto 'Eu', ou 'Nós', a não ser negativamente, por oposição a um 'outro', que ele tem que construir como figura antitética a fim de poder colocar-se a si mesmo como seu contrário [...]” (LANDOWSKI, 2016, p. 25, grifos do autor).

A apelação ao termo "ideologia de gênero" justifica-se por ser um símbolo de posicionamento do coletivo extrema direita. Sob o "tom" pejorativo do seu enunciado, agregado aos valores cristãos, produz-se um efeito de subversão que cria uma busca constante, uma motivação, uma "missão" que só os indivíduos do coletivo têm (mais uma vez recorrendo aos valores religiosos) de "desconstruir" o pensamento LGBT+, isto é, de desconstruir o outro para que ele pare de ser outro e passe a ser eu/nós. Acompanhe a Figura 13: 
Figura 13: Adesão identitário-majoritária dos grupos LGBT+ e anti-LGBT+

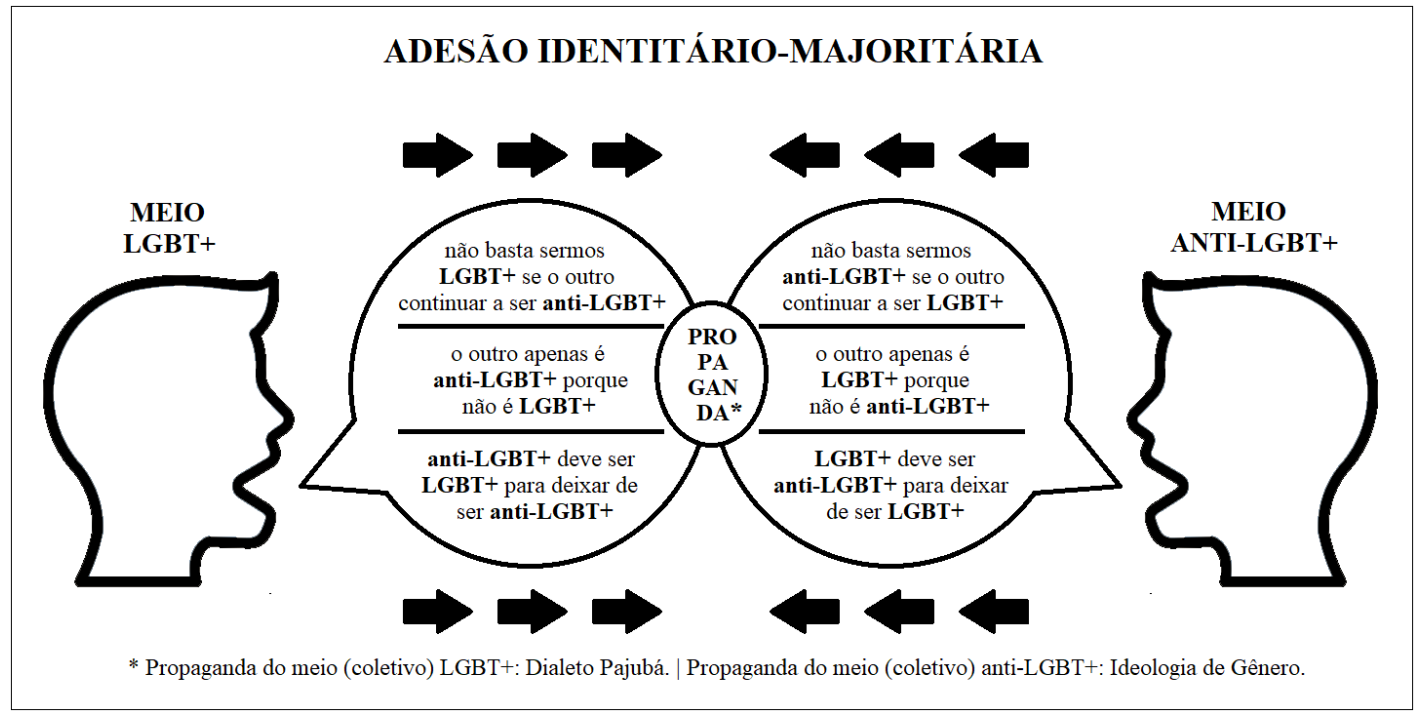

Fonte: Elaborada pelos autores.

O discurso anti-LGBT+, em primeira instância, espera atingir tanto o coletivo cristão, quanto os coletivos "psicologia" e "política", destinando-se a uma minoria que se enquadre na associação dos mesmos estereótipos que a enunciadora recupera em seu discurso, isto é, um "coletivo do coletivo". Esta minoria é constituída pelo grupo "habitante" do seu veículo de disseminação, neste caso, seus seguidores do Instagram.

Há, portanto, uma diferença entre os valores estereotípicos ativados por cada um dos coletivos na difusão de suas respectivas propagandas, bem como entre as situações impostas por cada um. Marisa Lobo, por ser uma figura política representando a voz de um "eu-coletividade", procura se tornar um corpo investido de valores para os seus seguidores. Produz, em vista disso, um discurso cuja fonte só pode ser esse modelo a ser seguido, cujo comportamento pressuposto por seus seguidores é um ideal a ser atingido, conforme a especificação de seu tom e da veracidade contida no seu discurso. "Por sua própria maneira de se enunciar, o discurso mostra uma regulação eufórica do sujeito que o sustenta e do leitor que ele pretende ter [...]" (MAINGUENEAU, 2013, p. 91).

A apelação desse discurso — validada pelo discurso de ódio — motiva a reação da enunciadora a adquirir um tom de agressividade, já que "quando um político de extrema direita mostra por sua enunciação a figura do homem do povo que diz a verdade nua e crua, que denuncia as falas mentirosas dos políticos "podres", ele define implicitamente o que é o discurso político legítimo [...]” (MAINGUENEAU, 2013, p. 78). Entretanto, “todo sistema de normas sociais [...] existe apenas em relação à consciência subjetiva dos 
indivíduos que pertencem a uma dada coletividade, direcionada por certas normas" (VOLÓCHINOV, 2017, p. 175).

Por isso, seria correto afirmar que o discurso da psicóloga já é, desde o início, planejado para ser direcionado a seu próprio grupo na polarização. Sua fala reativa certos discursos já disponíveis no seu arcabouço estereotípico para, por fim, projetar um ethos que corrobora com o estereótipo do seu coletivo e com a noção ideológica que este tem referente ao grupo antagonista: "se o ethos está crucialmente ligado ao ato de enunciação, não se pode ignorar, entretanto, que o público constrói representações do ethos do enunciador antes mesmo que ele fale" (MAINGUENEAU, 2013, p. 71), o que é análogo ao que o autor chama de ethos prévio ou ethos pré-discursivo. A presença dos dez argumentoschave serve, então, para a enunciadora "interagir" com seu público-alvo utilizando as noções ideológicas estereotípicas (culturais) que o coletivo tem em relação ao grupo LGBT+. Para elucidar essa interação, ilustramos o processo dos dez argumentos-chave no Quadro 2:

Quadro 2: Argumentos-chave da voz coletiva anti-LGBT+ estereotípica.

\begin{tabular}{|c|c|c|}
\hline $\begin{array}{l}\text { ARGUMENTO-CHAVE } \\
\text { (transcrição) }\end{array}$ & $\begin{array}{c}\text { VALIDAÇÃO } \\
\text { (a que ideia recorre de seu } \\
\text { arcabouço estereotípico) }\end{array}$ & $\begin{array}{l}\text { ETHOS IMPLICADO } \\
\text { (ethos produzidos) }\end{array}$ \\
\hline $\begin{array}{c}\text { ENEM } 2018 \text { TEVE ATÉ } \\
\text { DIALETO GAY? }\end{array}$ & $\begin{array}{l}\text { Referência à simplificação do } \\
\text { jargão Pajubá como "dialeto gay". }\end{array}$ & $\begin{array}{c}\text { Revolta } \\
\text { A questão sobre o Pajubá é a } \\
\text { "gota d'água". }\end{array}$ \\
\hline Isso é relevante? Socorro!!! & $\begin{array}{l}\text { É irrelevante mencionar o Pajubá } \\
\text { no Enem. }\end{array}$ & $\begin{array}{c}\text { Modernização } \\
\text { Referência à gíria “socorro", típica } \\
\text { da internet, cujo significado é o } \\
\text { mesmo, porém menos literal do } \\
\text { que o utilizado fora das } \\
\text { plataformas digitais. }\end{array}$ \\
\hline $\begin{array}{c}\text { Se BOLSONARO NÃO colocar } \\
\text { alguém }[\ldots]\end{array}$ & $\begin{array}{c}\text { A única solução plausível é eleger } \\
\text { o então candidato à presidência } \\
\text { Jair M. Bolsonaro, para que este } \\
\text { tome providências. }\end{array}$ & $\begin{array}{c}\text { Apelação } \\
\text { A enunciadora apela ao próprio } \\
\text { coletivo para a concretização da } \\
\text { solução apresentada por ela. }\end{array}$ \\
\hline [...] dessa desconstrução da identidade & $\begin{array}{l}\text { Noção pseudocientífica de que a } \\
\text { identidade humana é definida pelo } \\
\text { sexo biológico (sendo, portanto, } \\
\text { heterossexual e heteronormativa). }\end{array}$ & $\begin{array}{c}\text { Empatia coletiva } \\
\text { As concepções de orientação } \\
\text { sexual e identidade de gênero, } \\
\text { refletidas no jargão Pajubá, } \\
\text { desconstroem a identidade das } \\
\text { pessoas. }\end{array}$ \\
\hline
\end{tabular}




\begin{tabular}{|c|c|c|}
\hline essa tal diversidade sexual e de gênero & $\begin{array}{c}\text { Noção de que a diversidade sexual } \\
\text { e de gênero não pertence à } \\
\text { identidade do coletivo da } \\
\text { enunciadora. }\end{array}$ & $\begin{array}{c}\text { Acusação } \\
\text { A diversidade sexual e de gênero é } \\
\text { uma ideologia do coletivo } \\
\text { opositor. }\end{array}$ \\
\hline $\begin{array}{c}\text { se essa tal pessoa não souber sobre raízes } \\
\text { históricas, lógica }[. . .]\end{array}$ & $\begin{array}{l}\text { Noção pseudocientífica de que as } \\
\text { atuais concepções de sexualidade } \\
\text { e identidade de gênero vão contra } \\
\text { a ciência moderna (sobretudo a } \\
\text { Lógica e a História). }\end{array}$ & $\begin{array}{c}\text { Intelectualidade } \\
\text { O coletivo oposto não possui } \\
\text { conhecimentos de Lógica e } \\
\text { História (mas eu e meu coletivo } \\
\text { possuímos). }\end{array}$ \\
\hline $\begin{array}{c}\text { sobre o que a ciência e o mundo afirmam } \\
\text { sobre essa "falácia" }\end{array}$ & $\begin{array}{l}\text { Noção pseudocientífica de que as } \\
\text { atuais concepções de sexualidade } \\
\text { e identidade de gênero vão contra } \\
\text { a ciência moderna (não passando } \\
\text { de uma "falácia"). }\end{array}$ & $\begin{array}{l}\text { Representatividade } \\
\text { Represento a ciência e o mundo e } \\
\text { por isso posso afirmar que é tudo } \\
\text { "falácia". }\end{array}$ \\
\hline
\end{tabular}

\section{A educação não deve contemplar qualquer concepção acerca de diversidade sexual e de gênero.}

Não irá mudar nossa EDUCAÇ̃̃O

\section{Engajamento}

Enunciador do povo (como observa-se no uso do termo "nossa"), e mais uma vez pela representatividade científica.

\begin{tabular}{|c|c|c|}
\hline & & Proteção \\
\hline $\begin{array}{l}\text { Precisamos de alguém que tenha } \\
\text { conbecimento, estratégico e coragem para } \\
\text { mudar, enfrentar esses abusos }\end{array}$ & $\begin{array}{l}\text { A banca examinadora do Enem } \\
\text { não tem conhecimento estratégico } \\
\text { e abusou da população brasileira } \\
\text { ao referenciar o jargão Pajubá (e a } \\
\text { ideologia que ele representa). }\end{array}$ & $\begin{array}{l}\text { Aparenta ter o conhecimento da } \\
\text { resposta ou solução para esse } \\
\text { problema, que consistiria na } \\
\text { candidatura do então candidato } \\
\text { Jair M. Bolsonaro (supostamente } \\
\text { munido de conhecimento } \\
\text { estratégico e coragem). }\end{array}$ \\
\hline $\begin{array}{c}\text { Precisamos desconstruir essa } \\
\text { IDEOLOGLA DE GÊNERO NA } \\
\text { EDUCACÂO. É urgente }\end{array}$ & $\begin{array}{l}\text { Noção pejorativa de que o } \\
\text { conjunto das atuais concepções de } \\
\text { sexualidade e identidade de gênero } \\
\text { representam uma "ideologia de } \\
\text { gênero", mencionada } \\
\text { anteriormente neste artigo. }\end{array}$ & $\begin{array}{l}\text { Chamada destinada ao próprio } \\
\text { coletivo para que ocorra a } \\
\text { desconstrução da ideologia } \\
\text { representada pelo jargão Pajubá, a } \\
\text { "ideologia de gênero". }\end{array}$ \\
\hline
\end{tabular}

\section{Fonte: Elaborado pelos autores}

Observamos então que, primariamente, a reação da psicóloga frente ao caso foi envolvida em um sistema de defesa linguística identitário-ideológica. " $A$ importância de uma mudança ideologica deve ser definida no contexto da ideologia correspondente, considerando que qualquer área ideológica é uma totalidade que reage com toda a sua composição à alteração da base" (VOLÓCHINOV, 2017, p. 104, grifo do autor). Entretanto, esse sistema não é o único elemento a determinar a criação de um espectro polarizante: por ser discurso político disseminado em social media, há uma intenção discursiva muito forte de se atingir o próprio grupo de polarização, de modo a angariar "votos" representados, no Instagram, pelos likes, 
comments e followers. Essa intenção se baseia nas premissas não basta sermos isso se o outro continuar a ser aquilo; o outro apenas é aquilo porque não é isso; e aquilo deve ser isso para deixar de ser aquilo, constituindo a primeira instância de ethos discursivo (o ethos da preservação identitáriodiscursiva).

O conjunto de vocalidade e de tom escolhidos pela enunciadora é válido apenas aos membros da própria coletividade a partir da primeira instância de ethos, pois esse sistema de normas (estereótipo) associado à combatividade, ao falar a verdade "nua e crua", é uma característica estereotípica do coletivo vinculado ao meio da extrema-direita em associação com algumas ideologias cristãs, representando um extremismo ideológico. O meio antagonista (LGBT+, representado pelo Pajubá) só será referenciado, então, a partir do momento em que a instauração da primeira instância de ethos não for mais suficiente para provocar a adesão dos indivíduos a essa ideologia, acionando as premissas: não basta sermos isso se o outro continuar a ser aquilo; o outro apenas é aquilo porque não é isso; e aquilo deve ser isso para deixar de ser aquilo, que constituem a segunda instância de ethos discursivo (o ethos da adesão identitário-majoritária).

É este processo em si que provoca o movimento do espectro polarizante, uma vez que, a partir do direcionamento do segundo ethos aos leitores LGBT+s, estes instituem a sua defesa linguística (do coletivo LGBT+) e, para manter a integridade de sua identidade, lançam contradiscursos que restringem a persuasão e a efetividade desse ethos. Desse modo, o fenômeno de polarização discursiva poderia ser considerado cíclico: o lado A cria um discurso para atestar e legitimar sua identidade, enquanto o lado B lança um contradiscurso com as mesmas intenções agregadas à intenção de descreditar o discurso de A; lado A sente-se ameaçado e lança um novo contradiscurso, e assim sucessivamente.

\section{CONSIDERAÇÕES FINAIS}

Esse estudo discutiu as relações e distinções impressas no efeito de oposição entre as manifestações discursivas do meio LGBT+, expressas pelo jargão Pajubá, e o meio ultraconservador cristão associado a extrema direita anti-LGBT+, expressas pelo discurso da psicóloga Marisa Lobo na rede social Instagram. Para tanto, tivemos como questão norteadora a concepção de que o efeito de polarização surge como um modo de defesa social e linguística para manutenção da identidade de coletividades que prezam pela 
integridade de seu discurso e dos aspectos que as fazem pertencer a determinados conjuntos de valores e posicionamentos.

Em vista disso, o objetivo neste estudo foi compreender o processo de polarização entre o discurso de liberalismo social (pró-LGBT+), expresso pelo jargão Pajubá, e o discurso de conservadorismo social (anti-LGBT+), expresso pelo contradiscurso ultraconservador cristão. Demonstramos que sempre que houver essa expressão discursiva de uma voz "eu-coletividade", haverá uma reação linear contrária a ela, originada por uma VOz "eu-coletividade" antagonista, pois a única maneira de credibilizar a sua identidade é mostrando-a oposta à identidade do outro (uma coletividade é aquilo que a outra não é). Essa reação ocorre a partir do resgate dos valores estereotípicos da coletividade, constituídos desde suas ideologias até o tom e a vocalidade comuns à manifestação de seu discurso na sociedade.

Entretanto, esse processo pode ser potencializado pela intenção discursiva de determinados tipos de discurso e determinados espaços de disseminação, como é o caso do discurso político disseminado na social media, quando há uma preocupação em angariar votos e adesão (típica do discurso político) somada à preocupação de angariar likes, comments e followers, como pudemos observar pelo corpus estudado que refere-se a uma figura política, mas também digital influencer na rede social Instagram. A partir deste momento, o embate identitário-ideológico passa a ser coadjuvante de uma necessidade de autopromoção, necessária para o processo de legitimação e credibilidade do indivíduo enunciador, que busca o destaque de sua identidade individual (como indivíduo político e religioso) e de sua identidade coletiva (como meio ultraconservador cristão anti-LGBT+).

Compreendemos, então, que todo coletivo possui um conjunto de valores arquetípicos, isto é, um estereótipo de expressão de sua identidade que é ideológica. O próprio processo de expressão desse estereótipo por uma coletividade já é suficiente para originar um efeito de polarização discursiva. Nesse contexto, manifestações discursivas ideologicamente contrárias fazem pressão em polos opostos — o lado "a" força o lado "b" a criar um contradiscurso oposto a ele para representar a sua identidade, e vice-versa.

Nosso estudo contribui para a desmistificação de ideologias pejorativas acerca da manifestação enunciativa de minorias como a LGBT+, bem como da noção de que existem discursos identitários isentos de ideologias. Uma possível sequência para este estudo poderia dar atenção a questões ainda pouco esclarecidas, como os diferentes 
fiadores implicados no processo de resgate estereotípico ou de que forma ocorre a recepção desse discurso pelo grupo polarizador antagonista (público LGBT+). Do mesmo modo, uma análise mais aprofundada poderia ser feita levando em consideração o efeito da linguagem não-verbal (foto) para a construção de sentido do discurso da psicóloga Marisa Lobo, necessária para a formação de sentido de um discurso na plataforma Instagram.

Concluímos que a tarefa de reconhecer e legitimar uma forma de discurso alheia é relativa a fatores muito específicos. O discurso nos mostra que as relações entre os grupos sociais linguísticos são muito mais complexas do que estamos acostumados a pensar, uma vez que levam em consideração fatores contextuais que são fundamentais para a construção da identidade de todos os indivíduos do meio social. Nesse cenário, todo fenômeno linguístico regido por dois ou mais discursos polarizados pode ser considerado essencial à manutenção da conjuntura social heterogênea que é espelhada e explicitada pela língua.

Recebido para publicação em 18 de junho de 2020.

Aceito em 01 de agosto de 2020.

\section{REFERÊNCIAS}

AMOSSY, R. Da noção retórica de ethos à análise do discurso. In: Imagens de Si no Discurso. 2. ed. São Paulo: Contexto, 2013. p. 9-28.

BAGNO, M. A mitologia do preconceito linguístico. In: Preconceito Linguístico. 52. ed. São Paulo: Loyola, 2009. p. 23-92.

BOAVENTURA, L. H. Encenação e ubiqüidade em discursos no Twitter: procedimentos de análise. 135 f. Tese (Doutorado em Letras) - Programa de PósGraduação em Letras, Universidade de Passo Fundo, Passo Fundo, 2017.

CUNHA, L. F. B. O discurso homofóbico nas redes sociais e o confronto ideológico acerca da diversidade sexual no Brasil. 79 f. Dissertação (Mestrado em Letras) Programa de Pós-Graduação em Letras, Universidade Federal do Amazonas, Manaus, 2019.

CRUZ, L.; TITO, R. P. A comunidade LGBT no desdobramento da língua Iorubá. Cadernos do CNFL, Rio de Janeiro, v. 20, n. 12, 2016. p. 9-21.

FOLHA DE S. PAULO. Bolsonaro critica questão do Enem sobre gays e promete exame com temas 'úteis'. Disponível em: 
https://www1.folha.uol.com.br/educacao/2018/11/ bolsonaro-critica-questao-do-enem-sobre-gays-e-promete-exame-com-temas-uteis.shtml. Acesso em: 30/06/2020.

FREITAS, E. C.; BOAVENTURA, L. H. Cenografia e ethos: o discurso da intolerância e polarização política no Twitter. Letras de Hoje, Porto Alegre, v. 53, n. 3, julho de 2018. p. 449-458.

GGB - Grupo Gay da Bahia. População LGBT morta no Brasil. 2018.

JUNQUEIRA, R. D. "Ideologia de gênero": a invenção de uma categoria polêmica contra os direitos sexuais. In: RAMOS, M. M.; NICOLI, P. A. G.; ALKMIN, G. C. Gênero, Sexualidade e Direitos Humanos: Perspectivas Multidisciplinares. Initia Via, 2017. p. 221-235.

LANDOWSKI, E. Buscas de identidade, crises de alteridade. In: Presenças do

Outro: Ensaios de Sociossemiótica. 1. ed. São Paulo: Perspectiva, 2016. p. 3-29.

MAINGUENEAU, D. Ethos, cenografia, incorporação. In: AMOSSY, R. Imagens de Si no Discurso. 2. ed. São Paulo: Contexto, 2013. p. 69-92.

MILLER, Victor. Dicionário Pajubá: conheça alguns dos termos populares entre LGBTs. Disponível em: https://gay.blog.br/gav/dicionario-pajuba-conheca-alguns-dostermos-populares-entre-lgbts/. Acesso em: 30/06/2020.

VOLÓCHINOV, V. Marxismo e Filosofia da Linguagem. 1. ed. São Paulo: Editora 34, 2017. 


\title{
PAJUBÁ: MANIFESTATION OF ETHOS IN DISCURSIVE POLARIZATION
}

\begin{abstract}
The objective in this study is to understand the polarization process between the discourse of social liberalism (pro-LGBT + ) expressed by the Pajubá jargon and the discourse of social conservatism (anti-LGBT + ) expressed by the Christian ultraconservative counter-speech. We will use, for the analysis, the contributions of Volóchinov (2017) (Bakhtin Circle), related to the nature and the ideological manifestation of the statements; Landowski (2016) on identity and segregation in social linguistic groups; Maingueneau (2013) about the manifestations of the discursive ethos, in addition to complementary references. Our research is exploratory and bibliographic, with qualitative analysis. The corpus chosen for analysis is a post created by psychologist Marisa Lobo, on 5/11/2018, on the social network Instagram, referring to Pajubá. The study allows us to elucidate that ideologically opposed discursive manifestations put pressure on opposite sides - side " $a$ " forces side "b" to create a counter-discourse opposite to it to represent its identity, and vice versa.
\end{abstract}

Keywords: Pajubá; Ethos; LGBT. Identity; Polarization.

\section{PAJUBÁ: MANIFESTACIÓN DE ETHOS EN POLARIZACIÓN DISCURSIVA}

Resumen: El objetivo en esto estudio es comprender el proceso de polarización entre el discurso del liberalismo social (pro-LGBT+), expresado por la jerga Pajubá, y el discurso del conservadurismo social (anti-LGBT+), expresado por el contra-discurso cristiano ultraconservador. Usaremos, para el análisis, las contribuciones de Volóchinov (2017) (Circulo de Bakhtin) dirigidas a la naturaleza y la manifestación ideológica de los enunciados; Landowski (2016) sobre identidad y segregación en grupos linguísticos sociales; Maingueneau (2013) sobre las manifestaciones del ethos discursivo, además de referencias complementarias. Nuestra investigación es exploratoria y bibliográfica, con análisis cualitativo. El corpus elegido para el análisis es una publicación creada por la psicóloga Marisa Lobo, el 5/11/2018, en la red social Instagram, en referencia a Pajubá. El estudio nos permite dilucidar que las manifestaciones discursivas ideológicamente opuestas ejercen presión sobre los lados opuestos: el lado "a" fuerza al lado "b" para crear un contra-discurso opuesto al que representa su identidad, y viceversa.

Palabras claves: Pajubá; Ethos; LGBT; Identidad; Polarización.

Luis Henrique Boaventura - Doutor em Letras (UPF-2017). Bolsista PNPD/CAPES (UPF). Mestre em Letras pela Universidade de Passo Fundo (UPF-2013).

Kaian Lago - Graduado em Letras - Português/Inglês e Respectivas Literaturas pela Universidade de Passo Fundo. Voluntário de Iniciação Científica.

Ernani Cesar de Freitas - Doutor em Letras (PUCRS) com pós-doutorado em Linguística Aplicada e Estudos da Linguagem (PUC-SP); professor permanente do Programa de Pós-Graduação em Letras da Universidade de Passo Fundo. 